\title{
Malignant perineal tumors in dogs: the contribution of computed tomography for staging and surgical planning ${ }^{1}$
}

\author{
Carla A.B. Lorigados ${ }^{2 *}$, Ana Carolina C.B. Fonseca Pinto ${ }^{3}$, Julia Maria Matera ${ }^{3}$, \\ and Diego F.A. Modena ${ }^{3}$
}

\begin{abstract}
Lorigados C.A.B, Fonseca Pinto A.C.C.B., Matera J.M. \& Modena D.F.A. 2018. Malignant perineal tumors in dogs: the contribution of computed tomography for staging and surgical planning. Pesquisa Veterinária Brasileira 38(12):2241-2245. Departamento de Cirurgia, Faculdade de Medicina Veterinária e Zootecnia, Universidade de São Paulo, Avenida Prof. Dr. Orlando Marques de Paiva 87, Cidade Universitária, São Paulo, SP 05508-270, Brazil. E-mail: clorigados@usp.br

The contribution of computed tomography for staging and surgical planning of malignant perineal tumors in dogs is discussed. Five dogs diagnosed with malignant perineal neoplasms underwent to computed tomography (CT) examination. The CT image enabled investigation of cleavage planes between neoplastic lesions and adjacent structures such as the rectum, anus, vagina, urethra and perineal muscles. Accurate assessment regional lymph nodes and adjacent bone structures was also possible. All tumors evaluated in this region presented heterogeneous appearance in pre and postcontrast CT images, but only the anal sac adenocarcinomas presented lymphadenopathy. Computed tomography proved to be a valuable tool for tumor staging and determination of lesion extension and invasion of adjacent tissues, providing significant contributions to clinical and surgical therapeutic planning.
\end{abstract}

INDEX TERMS: Malignant perineal tumor, computed tomography, surgical planning, dogs, image diagnosis.

\begin{abstract}
RESUMO.- [Tumores perineais malignos em cães: contribuição da tomografia computadorizada para estadiamento e planejamento cirúrgico.] A contribuição da tomografia computadorizada para estadiamento e planejamento cirúrgico de tumores perineais malignos em cães é discutida. Cinco cães diagnosticados com neoplasias perineais malignas foram submetidos ao exame de tomografia computadorizada (CT). A imagem por TC permitiu a investigação de planos de clivagem entre as lesões neoplásicas e estruturas adjacentes, como o reto, o ânus, a vagina, a uretra e os músculos perineais. A avaliação precisa dos linfonodos regionais e estruturas ósseas adjacentes também foi possível. Todos os tumores avaliados nesta região apresentaram aspecto heterogêneo nas imagens
\end{abstract}

\footnotetext{
${ }^{1}$ Received on June 11, 2018.

Accepted for publication on August 29, 2018.

${ }^{2}$ Departamento de Cirurgia (VCI), Faculdade de Medicina Veterinária e Zootecnia (FMZV), Universidade de São Paulo (USP), Avenida Prof. Dr. Orlando Marques de Paiva 87, Cidade Universitária, São Paulo, SP 05508-270, Brazil. *Corresponding author: clorigados@usp.br

${ }^{3}$ Departamento de Cirurgia (VCI), Faculdade de Medicina Veterinária e Zootecnia (FMZV), Universidade de São Paulo (USP), Avenida Prof. Dr. Orlando Marques de Paiva 87, Cidade Universitária, São Paulo, SP 05508-270.
}

de TC pré e pós-contraste, mas apenas os adenocarcinomas de saco anal apresentaram linfonodopatia. A tomografia computadorizada mostrou ser uma ferramenta valiosa para o estadiamento da neoplasia, determinação da extensão da lesão e invasão de tecidos adjacentes, proporcionando contribuições significativas para o planejamento terapêutico clínico e cirúrgico.

TERMOS DE INDEXAÇÃO: Tumor perineal maligno, tomografia computadorizada, planejamento cirúrgico, caninos, diagnóstico por imagem.

\section{INTRODUCTION}

The perineal region is potential location for the development of neoplasms in dogs. The majority of the malignant tumors affecting this region arise from these glandular tissues being circumanal and anal sac adenocarcinomas the most common ones (Turek \& Withrow 2013). Circumanal glands are sebaceous glands located around the anus and anal sacs are cutaneous diverticula lined with serous and sebaceous glands and located on either side of the ventrolateral aspect 
of the anus, between the internal and external sphincters (Dyce et al. 2002)

Circumanal adenocarcinomas affect neutered and intact male and female dogs and do not seem to be hormone dependent. Higher predisposition has been reported in large breed males aged 11 years on average. Circumanal adenocarcinomas are associated with low metastatic rates, approximately $15 \%$ (Vail et al. 1990)

As regards apocrine gland adenocarcinoma of the anal sac, some authors suggest higher predisposition in older female dogs (Goldschmidt \& Zoltowski 1981, Ross et al. 1991), while others report no gender predisposition (Williams et al. 2003, Polton et al. 2006, Polton \& Brearley 2007). Spaniels, particularly English Cocker Spaniels, seem to be at higher risk of anal sac apocrine gland adenocarcinoma development (Polton et al. 2006), with mean age at diagnosis ranging from 9 to 11 years (Goldschmidt \& Zoltowski 1981, Ross et al. 1991, Williams et al. 2003). Anal sac apocrine gland adenocarcinomas are invasive tumors with highly variable rates of metastasis formation (36\% to $72 \%$ ), although metastasis formation rates of approximately $50 \%$ are reported in most studies (Ross et al. 1991, Williams et al. 2003, Emms 2005, Polton \& Brearley 2007). Regional lymph nodes, including sacral, internal iliac and medial iliac lymph nodes, are the most common metastatic sites (Williams et al. 2003, Emms 2005, Polton et al. 2006, Polton \& Brearley 2007). Distant metastases are rare and tend to occur in the most advanced stages of the disease. The liver, spleen, kidneys, pancreas, adrenal glands, heart, lungs, mediastinum and bones may be affected (Ross et al. 1991, Turek et al. 2003, Williams et al. 2003, Brisson et al. 2004, Emms 2005, Polton et al. 2006, Polton \& Brearley 2007).

Lymphomas, soft tissue sarcomas, squamous cell carcinomas, melanomas and mast cell tumors (MCTs) are other examples of malignant neoplasms that may affect the perineal region (Turek et al. 2003, Turek \& Withrow 2013).

Advanced diagnostic imaging modalities are routinely used for cancer patient staging in human medicine. In contrast, in veterinary medicine, thoracic radiography and abdominal ultrasonography (US) are still the most commonly tools used due to wider availability and lower cost of these methods. However, with the growing availability of computed tomography (CT) scanners, this diagnostic imaging modality has being increasingly used for cancer staging purposes in veterinary patients, particularly for lymph node assessment (Rossi et al. 2011, Grosso et al. 2017).

This study set out to investigate the contribution of CT for staging and surgical planning in dogs affected with malignant perineal tumors, bearing in mind the invasive and metastatic nature of some malignant tumors that affect this region.

\section{MATERIALS AND METHODS}

Five dogs with cytologically and/or histologically confirmed diagnosis of perineal malignant tumors that underwent to CT examination from January 2013 to April 2015 were included in this study. Following initial physical examination, chest radiography and transabdominal ultrasonography examinations were performed in order to search for distant metastasis. Perineal and caudal abdominal CT scanning was then performed to assess the tumor and the regional lymph nodes as an effort to collect useful data for surgical planning. A single row detector helicoidal CT scanner ${ }^{1}$ was used and pre and postcontrast transverse images cross-sectional images were acquired with 2 to $3 \mathrm{~mm}$ slice thickness and same increment. Postcontrast images were acquired following intravenous bolus administration of $1.5 \mathrm{ml} / \mathrm{kg}$ of a $300 \mathrm{mgI} / \mathrm{ml}$ non-ionic iodinated contrast agent solution ${ }^{2}$. Pre and postcontrast neoplasm attenuation were evaluated. Tumor longest one-dimensional diameter was determined using the RECIST method; volumetric measurements were also obtained. The presence of cleavage planes between neoplastic lesions and adjacent structures and the involvement of regional lymph nodes and bone structures (i.e. caudal lumbar vertebrae, sacrum and hip bone) were investigated.

\section{RESULTS}

Signalment and clinical features of the five patients evaluated over the course of the study period are presented in Table 1. Dyschezia was the most prominent clinical manifestation in four out of five dogs. Neoplasms presented as firm and sessile masses on clinical examination; ulceration was noted in two cases. Cytological and/or histological examination revealed well-differentiated anal sac adenocarcinomas (Cases 1,2 and 4), hemangiosarcoma (Case 3) and MCT (Case 5).

No radiographic changes in lungs, mediastinum or pleural spaces were noted. Enlarged, hypoechoic medial iliac lymph nodes (two cases; Dogs 1 and 4) were the only sonographic abnormal findings. Computed tomographic assessment revealed slightly heterogeneous soft tissue attenuation and moderate postcontrast enhancement in adenocarcinomas and MCT. Heterogeneous postcontrast enhancement were noted in anal sac adenocarcinomas and hemangiosarcoma (Table 2). With the exception of the MCT, no cleavage planes were detected between neoplasms and the rectal wall (Fig.1B and 1D) or local muscles (e.g. internal obturator, external anal sphincter, coccygeal muscle, levator ani, ventral, lateral and medial sacrocaudal muscles). Cleavage planes were also lacking between the neoplasm and the dorsal vaginal wall and the urethra in one female (Case 4) and one male (Case 1) respectively. Significantly enlarged medial iliac (Fig.2A), internal iliac (Fig.2B) and sacral (Fig.1A and 1C) lymph nodes were noted in two dogs (Dogs 1 and 4). One dog (Dog 4) also had enlarged caudal mesenteric and aortic lumbar lymph nodes (Fig.3). Enlarged lymph nodes presented mainly round shape; heterogeneous particularly peripheral enhancement. No changes were noted in the bones evaluated.

The owners of Dogs 1 and 4 declined surgical procedure because of the presence of metastasis in pelvic and abdominal lymph nodes and the possibility of resection of part of the anal sphincter, which may lead to fecal incontinence. In Dogs 2 and 3 it was possible to resect the tumor, preserving the anal sphincter, but without safety margin. In the dog with MCT it was possible to remove the tumor completely, with adequate surgical margin.

\section{DISCUSSION}

The surgery is used as the primary treatment option for dogs presenting perineal tumors. Studies with dogs affected by perineal neoplasia report longer survival time in patients

\footnotetext{
Model XPRESS/G6, Toshiba.

2 Omnipaque $300^{\circledR}$. GE Healthcare do Brasil, Comércio e Serviços para Equipamentos Médicohospitalares LTDA.
} 
Table 1. Patient signalment, affected site and tumor type

\begin{tabular}{clll}
\hline Dog & \multicolumn{1}{c}{ Breed, gender, age } & \multicolumn{1}{c}{ Affected site } & \multicolumn{1}{c}{ Cytology/Hystology } \\
\hline 1 & Cocker, male, 12 years & Dorsolateral to anus, rightsided & Anal sac adenocarcinoma \\
2 & Poodle, female, 14 years & Dorsolateral to anus, leftsided & Anal sac adenocarcinoma \\
3 & Labrador, female, 12 years & Ventrolateral to anus, rightsided & Hemangiosarcoma \\
4 & Cocker, female, 12 years & Lateral to anus, rightsided & Anal sac adenocarcinoma \\
5 & Brazilian terrier, male, 12 years & Perianal, rightsided & Mast cell tumor
\end{tabular}

Table 2. Tomographic features, tomographic measurements and lymph node involvement

\begin{tabular}{|c|c|c|c|c|c|}
\hline Dog & Attenuation & Post-contrast enhancement & $\begin{array}{l}\text { One-dimensional } \\
\text { measurement } \\
(\text { RECIST } / \mathrm{cm})^{\mathrm{a}}\end{array}$ & $\begin{array}{l}\text { Volumetric measurement } \\
\qquad\left(\mathrm{cm}^{3}\right)\end{array}$ & Lymphadenomegaly \\
\hline 1 & $\begin{array}{l}\text { Slightly } \\
\text { heterogeneous }\end{array}$ & Moderate/slightly heterogeneous & 8.08 & 143.964 & $\begin{array}{l}\text { Medial iliac, internal iliac } \\
\text { and sacral }\end{array}$ \\
\hline 2 & $\begin{array}{l}\text { Slightly } \\
\text { heterogeneous }\end{array}$ & Moderate/heterogeneous & 5.16 & 75.235 & No \\
\hline 3 & Heterogeneous & Intense/heterogeneous & 7.51 & 87.484 & No \\
\hline 4 & $\begin{array}{l}\text { Slightly } \\
\text { heterogeneous }\end{array}$ & Intense/heterogeneous & 9.31 & 220.908 & $\begin{array}{l}\text { Medial iliac, internal iliac, } \\
\text { sacral, aortic lumbar and } \\
\text { caudal mesenteric }\end{array}$ \\
\hline 5 & $\begin{array}{l}\text { Slightly } \\
\text { heterogeneous }\end{array}$ & Moderate/heterogenous & 5.17 & 78.347 & No \\
\hline
\end{tabular}

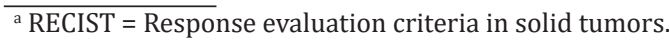
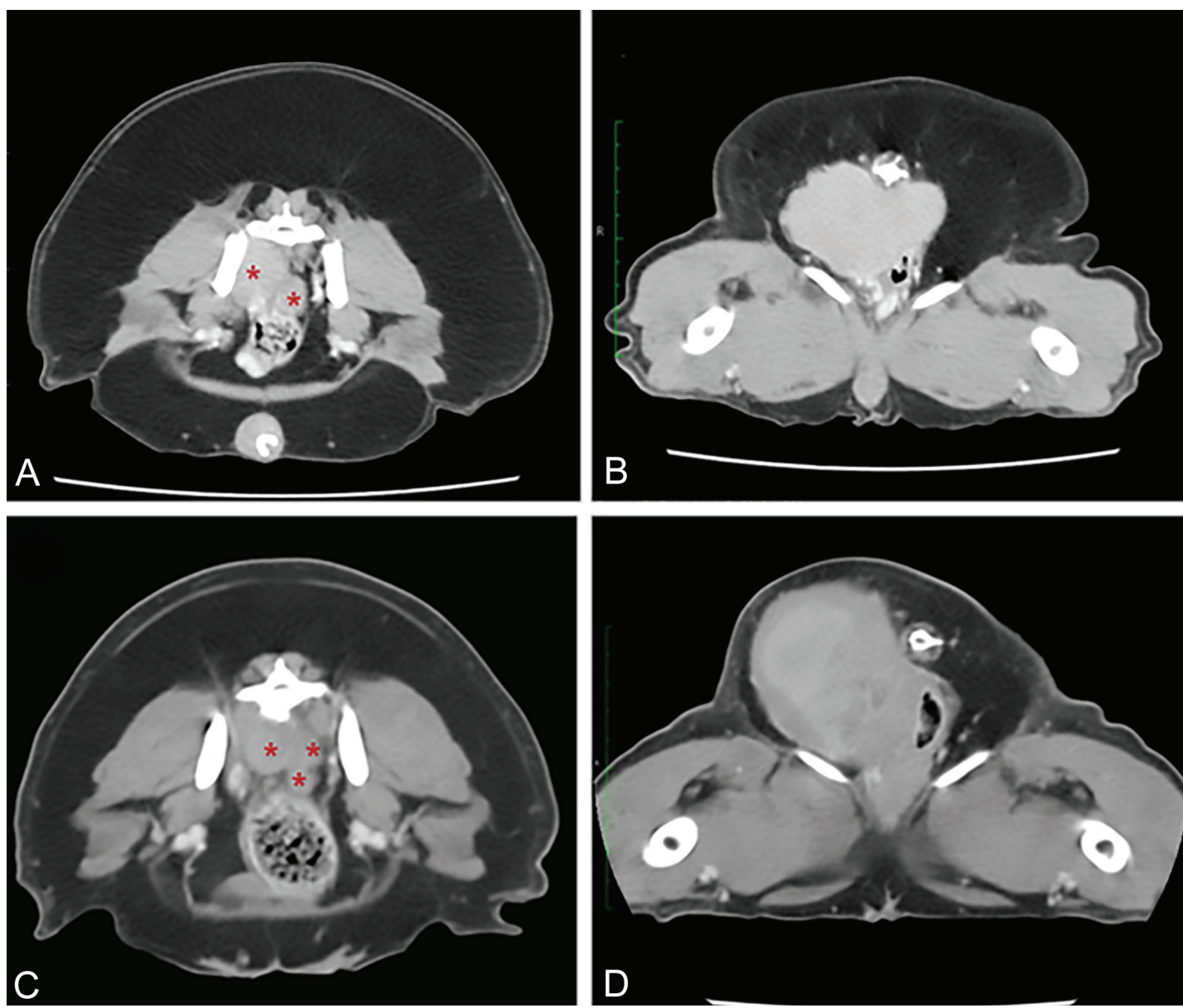

Fig.1. Post-contrast transverse CT images of dogs with anal sac adenocarcinoma in (A,B) Case 1 and (C,D) Case 4. (A,C) Enlarged sacral lymph nodes with rounded shape were observed $\left(^{*}\right)$. (B,D) No cleavage plane was detected between neoplasms and the rectal wall. 

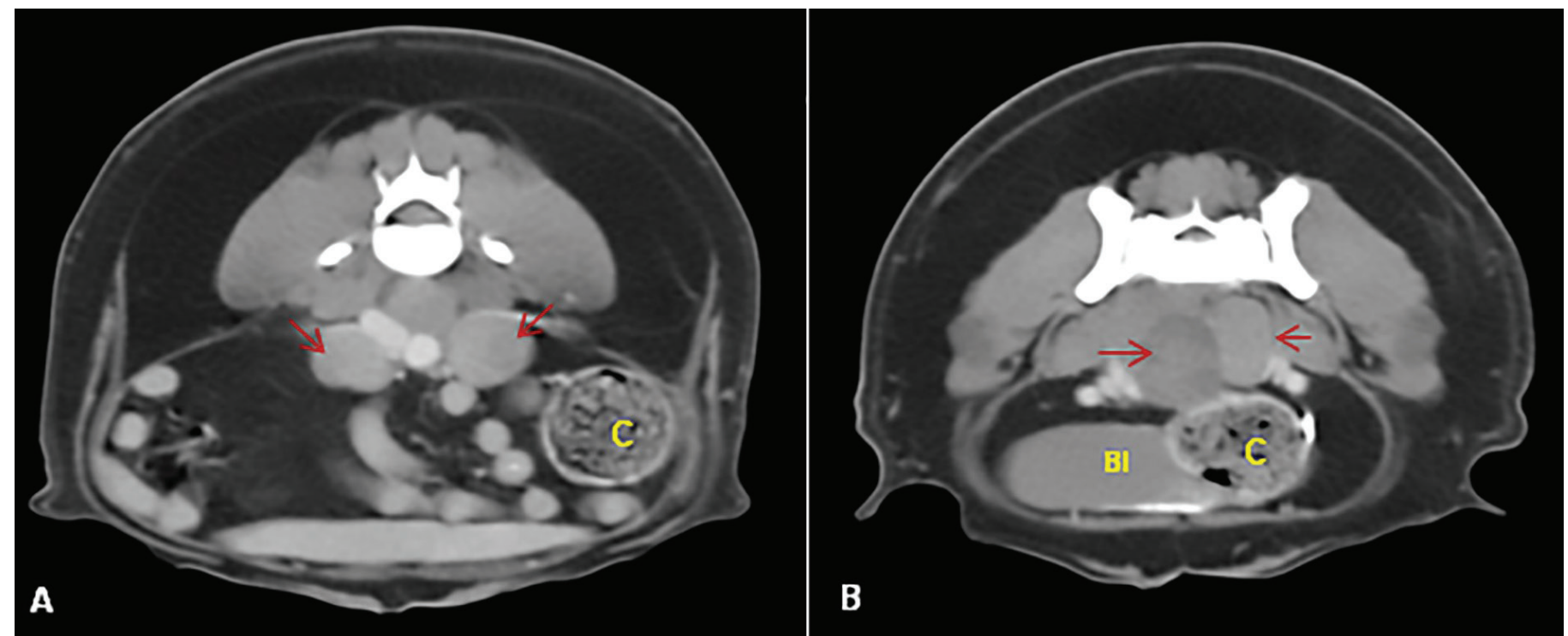

Fig.2. Post-contrast transverse CT images of a dog with anal sac adenocarcinoma (Case 4). (A) Enlarged medial iliac and (B) internal iliac lymph nodes are observed (arrows). $\mathrm{C}=$ colon, $\mathrm{Bl}=$ bladder.
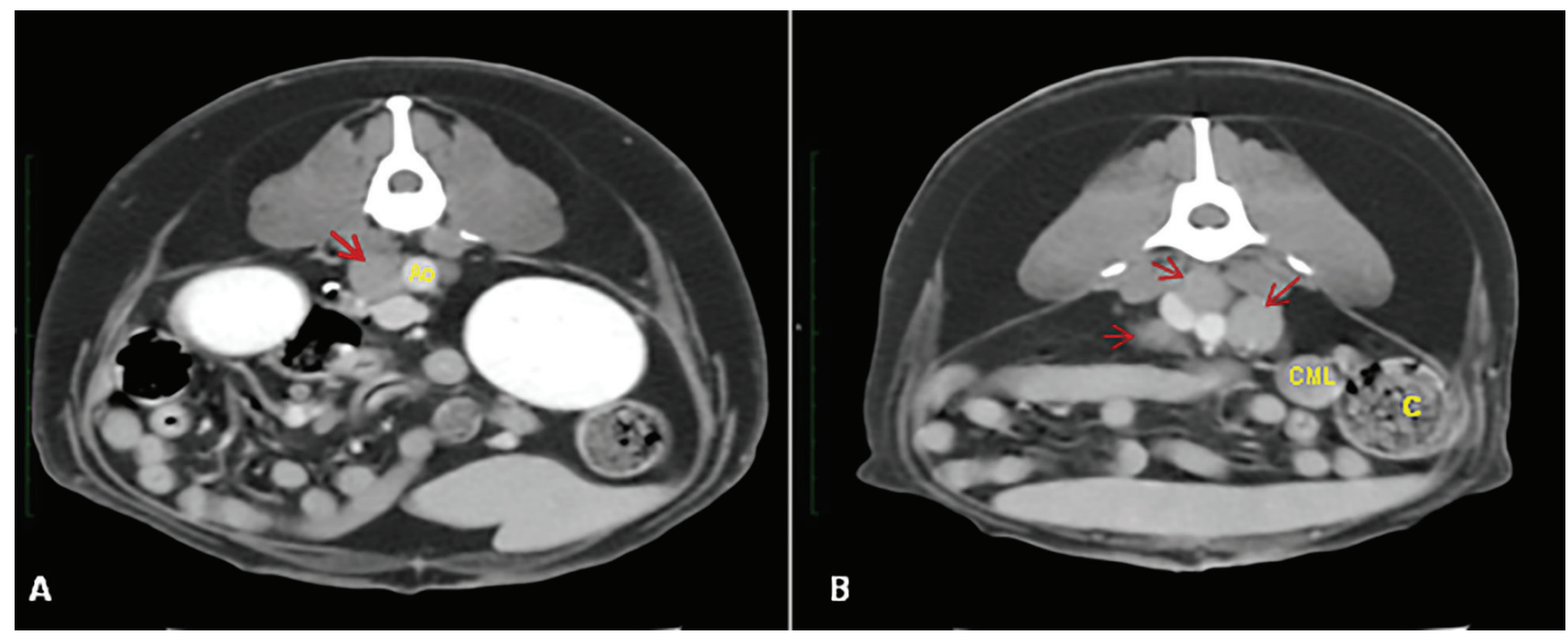

Fig.3. Post-contrast transverse CT images of a patient with anal sac adenocarcinoma (Case 4). (A) Enlarged aortic lumbar lymph nodes (arrow) and (B) caudal mesenteric (CLM) lymph nodes with enlarged medial iliac and internal iliac lymph nodes (arrows). Ao $=$ aorta, $\mathrm{C}=$ colon.

submitted to multimodal therapeutic approaches combining surgical resection, chemo and radiotherapy as indicated (Vail et al. 1990, Bennett et al. 2002, Dyce et al. 2002, Polton \& Brearley 2007, Palladino et al. 2016, Barnes \& Demetriou 2017). Surgical margins are a significant factor in tumor resection. Cleavage planes between neoplastic lesions and different important perineal structures were lacking in patients in this sample. For the anal sac carcinomas, a segmental resection of the anal sphincter is required when the neoplasia reaches enormous proportions. The resections involving more than $180^{\circ}$ of the sphincter circumference may be associated with partial or complete fecal incontinence. When the sphincter can be preserved, the surgical margins may not be adequate, increasing the probability of local recurrence. Hence, initial treatment with chemotherapy was recommended to promote tumor volume reduction prior to surgery. Chemotherapy was also indicated as palliative treatment for patients with signs of metastatic dissemination to regional lymph nodes; in such cases, owners were informed of the guarded to poor prognosis. Metastatic lymph nodes can be removed by open ventral midline coeliotomy. Some lymph nodes are straightforward to excise for experienced surgeons, whilst others, mainly the sacral lymph nodes, are difficult to remove by this access (Barnes $\&$ Demetriou 2017) and a pubic osteotomy is necessary. 
Ultrasonography is thought to be a valuable imaging modality for abdominal lymph node evaluation. However, location of major sites of metastasis, such as the sacral and internal iliac lymph nodes (Vail et al. 1990, Dyce et al. 2002, Turek \& Withrow 2013), makes sonographic assessment difficult. Recently, CT and magnetic resonance imaging (MRI) have been shown be more sensitive than ultrasound in identifying lymphadenopathy in dogs with adenocarcinoma of the anal sac (Anderson et al. 2015, Palladino et al. 2016) Also, CT provided complementary assessment of bones in the search for metastasis which, although uncommon, may still occur (Turek \& Withrow 2013).

\section{CONCLUSIONS}

All tumors evaluated in this region presented heterogeneous appearance in pre and post-contrast CT images, but only the anal sac adenocarcinomas presented lymphadenopathy.

Inherent characteristics of computed tomography, volume contour mapping, detection of cleavage planes between neoplastic lesions and adjacent structures and tumor staging data, make it a suitable method in order to offer a better clinical and surgical management of patients with perineal tumor.

\section{REFERENCES}

Anderson C.L., Mackay C.S., Roberts G.D. \& Fidel J. 2015. Comparison of abdominal ultrasound and magnetic resonance imaging for detection of abdominal lymphadenopathy in dogs with metastatic apocrine gland adenocarcinoma of the anal sac. Vet. Comp. Oncol.13(2):98-105. <http:// dx.doi.org/10.1111/vco.12022><PMid:23432735>

Barnes D.C. \& Demetriou J.L. 2017. Surgical management of primary, metastatic and recurrent anal sac adenocarcinoma in the dog: 52 cases. J. Small Anim. Pract. 58(5):263-268. <http://dx.doi.org/10.1111/jsap.12633> <PMid:28245066>

Bennett P.F., Denicola D.B., Bonney P., Glickman N.W. \& Knapp D.W. 2002. Canine anal sac adenocarcinomas: clinical presentation and response to therapy. Survival 16(1):100-104. <PMid:11822797>

Brisson B.A., Whiteside D.P. \& Holmberg D.L. 2004. Metastatic anal sac adenocarcinoma in a dog presenting for acute paralysis. Can. Vet. J. 45(8):678-681. <PMid:15368742>

Dyce K.M., Sack W.O. \& Wensing C.J.G. 2002. Tegmunto comum, p.341-358. In: Dyce K.M., Sack W.O. \& Wensing C.J.G. (Eds), Tratado de Anatomia Veterinária. $2^{\mathrm{a}}$ ed. Elsevier, Rio de Janeiro.
Emms S.G. 2005. Anal sac tumors of the dog and their response to cytoreductive surgery and chemotherapy. Aust. Vet. J. 83(6):340-343. <http://dx.doi. org/10.1111/j.1751-0813.2005.tb15626.x> <PMid:15986909>

Goldschmidt M.H. \& Zoltowski C. 1981. Anal sac gland adenocarcinoma in the dog: 14 cases. J. Small Anim. Pract. 22(3):119-128. <http://dx.doi. org/10.1111/j.1748-5827.1981.tb00591.x><PMid:7230749>

Grosso F.V., Lim C.K., Heng H.G. \& Childress M. 2017. Computed tomographic features of canine anal sac apocrine gland adenocarcinoma. Proceedings European Veterinary Diagnostic Imaging, Verona, Veneto, p.166-167.

Palladino S., Keyerleber M.A., King R.G. \& Burgess K.E. 2016. Utility of computed tomography versus abdominal ultrasound examination to identify iliosacral lymphadenomegaly in dogs with apocrine gland adenocarcinoma of the anal sac. J. Vet. Intern. Med. 30(6):1858-1863. <http://dx.doi.org/10.1111/ jvim.14601 ><PMid:27774696>

Polton G.A. \& Brearley M.J. 2007. Clinical stage, therapy and prognosis in canine anal sac gland carcinoma. J. Vet. Intern. Med. 21(2):274-280. <http:// dx.doi.org/10.1111/j.1939-1676.2007.tb02960.x> <PMid:17427388>

Polton G.A., Mowat V., Lee H.C., Mckee K.A. \& Scase T.J. 2006. Breed, gender and neutering status of british dogs with anal sac gland carcinoma. Vet. Comp. Oncol. 4(3):125-131.<http://dx.doi.org/10.1111/j.1476-5829.2006.00100. $\mathrm{x}><$ PMid:19754809>

Ross J., Scavelli T., Matthiesen D. \& Patnaik A. 1991. Adenocarcinoma of the apocrine glands of the anal sac in dogs: a review of 32 cases. J. Am. Anim. Hosp. Assoc. 27(3):349-355.

Rossi F., Patsikas M.N. \& Wisner E.R. 2011. Abdominal lymph nodes and lymphatic collecting, p.371-379. In: Schwarz T. \& Saunders J. (Eds), Veterinary Computed Tomography. John Wiley \& Sons, Chichester.

Turek M.M. \& Withrow S.J. 2013. Cancer of the gastrointestinal tract, p.423431. In: Withrow S.J. \& Vail D.M. (Eds), Small Animal Clinical Oncology. 5th ed. W.B. Saunders Elsevier, St Louis.

Turek M.M., Forrest L.J., Adams W.M., Helfand S.C. \& Vail D.M. 2003. Postoperative radiotherapy and mitoxantrone for anal sac adenocarcinoma in the dog: 15 cases (1991-2001). Vet. Comp. Oncol. 1(2):94-104. <http://dx.doi. org/10.1046/j.1476-5829.2003.00013.x> <PMid:19379321>

Vail D.M., Withrow S.J., Schwarz P.D. \& Powers B.E. 1990. Perianal adenocarcinoma in the canine male: a retrospective study of 41 cases. J. Am. Anim. Hosp. Assoc. 26(3):329-334.

Williams L.E., Gliatto J.M., Dodge R.K., Johnson J.L., Gamblin R.M., Thamm D.H., Lana S.E., Szymkowski M. \& Moore A.S. 2003. Carcinoma of the apocrine glands of the anal sac in dogs: 113 cases (1985-1995). J. Am. Vet. Med. Assoc. 223(6):825-831.<http://dx.doi.org/10.2460/javma.2003.223.825> $<$ PMid:14507100> 